memory methods used by actors and an interesting anti-associationist view of mediators.

Two short essays complete the book. One on retroactive inhibition, written in 1940, is very dull. The other on the Russian work on the interrelation between verbal processing and imagery is more interesting and less antiquated but made somewhat dubious by the lack of any information-processing type concepts.

This book therefore cannot be recommended for any type of readership. On the evidence of this and two others in the same series it is unfortunate that Russian work on the higher mental processes has only been translated long after it could have had a beneficial effect on Western work. Whether translation of recent Russian work would be more productive remains unclear.

\section{T. Shallice}

\section{Ancient Egyptians}

Population Biology of the Ancient Egyptians. Edited by D. R. Brothwell and B. A. Chiarelli. Pp. 560. (Academic: London and New York, June 1973.) £7.

THIs volume contains thirty-two papers, twenty-nine of which, presented at a symposium held in Italy in 1969, have already appeared in the Journal of Human Evolution. Pagination is chaotic, and typographical errors abound. Some could create difficulties for students checking sources. Glaring, although relatively innocuous, is the ascription (in both the text and bibliography of Gray's paper on the radiography of mummies) of Harris's work on bone growth to H. A. Hains. The sequence of subjects follows no consistent plan. It is regrettable that a work commemorative of Sintoff should not be better produced since it contains much of great interest.

The papers cover almost every aspect of the biology of the Ancient Egyptians and present them as a homogeneous group, living in relative isolation and a stable environment throughout a very long period. They thus afford a unique opportunity for the study of human micro-evolution in response to a limited number of identifiable factors. Inevitably the papers vary in value. Among the most stimulating are the demonstration by Raikes and Palmieri of the stability of the physical environment for at least 10,000 years; the indication by Masali and Chiarelli of differing mortality patterns in the Pre-dynastic and Dynastic periods; the controversial claim by Nemeskéri that population growth in Egypt and Eurasia depended solely on a fall in mortality rate (factors affecting fertility must play a part!) and the study by Saffirio of Egyptian diet and its calorie content.
Interesting papers based on work with skeletons and mummies include the studies by Bourke and by Satinoff of skeletal trauma and its treatment (the claim of the latter that the Egyptians could not reduce impacted fractures because of the lack of anaesthetics seems far-fetched, when even amputations were effected in the past without them); the re-emphasis by Borgognini-Tarli of the uncertainties of blood group determination on ancient remains; the salutary critique by Sandison of attempts to diagnose pathological conditions in surviving soft tissues; the excellent papers on skeletal and dental evolution and pathology (Greene's is a most meticulous study) indicating early occurrence of third molar suppression, an epidemic outbreak of caries concomitant with the domestication of cereals, and sexual convergence in bodily morphology following the expansion of agriculture; the contribution by Michelin-Lausarot to the new field of biochemical study of tissue breakdown in preserved organic material; the paper by Stouhal containing data possibly important for the study of the racial history of East Africa. Davide's list of mummies, skeletons and skulls throughout the world is valuable and its appearance here may lead to its amplification, since many small museums house specimens. The book is a very useful compendium.

H. Hughes

\section{Notes on Nutrition}

Notes on the History of Nutrition Research. By Clive M. McCay. Edited by F. Verzár. Pp. 234. (Stuttgary: Berne; Hans Huber: Vienna, 1973.) 42 francs; 38 DM.

THIs book is needed for reference in libraries dealing with nutrition in the widest sense. It contains the notes for lectures on the history of nutrition studies by Professor Clive M. McCay of Cornell University, and has been published owing to the enterprise of Professor F. Verzár and the late Professor Maynard. I had the privilege of knowing McCay during a sabbatical period which he spent in my laboratory in Oxford, and on subsequent visits to him. He was an original thinker as well as being a fine scholar and a courageous man. Science has lost an important work through the illness which prevented him from finishing his book. As it is, the notes do not go much beyond 1920; they deal in order with fats, nitrogen, protein and inorganic substances. McCay has dealt in depth and with penetration with literature going back 150 years and earlier, so that it is an education to read through these notes. It is an effort which should be made by anyone who wishes to lecture with depth on nutritional subjects. Some of
McCay's most original work dealt with the effect of nutrition on longevity; rats were shown to remain much younger if fed less than normal amounts of a complete diet during the period of growth. I have found a few misprints, none of which can mislead the reader. Rudolph A. Peters

\section{Foraminifera}

Distribution and Ecology of Living Benthic Foraminiferids. By John W. Murray. Pp. xii $+274+12$ plates. (Heinemann: London, June 1973.) $£ 7.50$.

THE successful application of foraminifera to subsurface problems in the oil industry has led to a burgeoning interest in their recent ecology and to the second book in a decade on their world distribution. This compilation differs in being based entirely on records of living specimens. Data from different authors are brought together and presented in a uniform manner largely through diversity plots, based on the now unfashionable Fisher $\alpha$ index, and triangular plots of the main suborders. This is a valuable synthesis though the individual sections are rather brief and tend to fall between the requirements of the research worker and the interested non-specialist.

The restriction to living records raises the problem of adequate sample control. Methods are still on the whole crude and stations sparse. The Phleger corer which provides the necessary undisturbed surface material only works on certain bottoms. Furthermore, living individuals are generally swamped by the dead. This has driven the author to abandon the counts of 250-300 individuals recommended in the Appendix and settle for 100 . Even then many samples fall short of the required numbers though comment on them is included. These difficulties would better have been fully discussed in the introduction.

Perhaps partly because of these problems, results are expressed in terms of relative per cent rather than absolute numbers, in spite of the admitted difficulties and the trouble taken to standardise area/volume. Unfortunately, this tends to perpetuate the unwarranted notion of a reciprocal relation between species. They may be neutral rather than competing.

The second paragraph of the preface should not be taken too seriously because palaeoecologic reconstruction is necessarily based on the fossilised remnant of the death assemblage. Indeed, the thanatocoenose may better represent total foraminiferal production over a period, precisely because of current mixing, despite the "veil of the Pleistocene". JOHN R. HAYNES 